Relations industrielles

Industrial Relations

\title{
The Dirty Work of Neoliberalism: Cleaners in the Global Economy, Edited by Luis L.M. Aguiar and Andrew Herod, Oxford: Blackwell Publishing, 2006, 272 pp., ISBN 9781405156363.
}

\section{Travis William Fast}

Volume 65, numéro 1, hiver 2010

URI : https://id.erudit.org/iderudit/039533ar

DOI : https://doi.org/10.7202/039533ar

Aller au sommaire du numéro

Éditeur(s)

Département des relations industrielles de l'Université Laval

ISSN

0034-379X (imprimé)

1703-8138 (numérique)

Découvrir la revue

Citer ce compte rendu

William Fast, T. (2010). Compte rendu de [The Dirty Work of Neoliberalism: Cleaners in the Global Economy, Edited by Luis L.M. Aguiar and Andrew Herod, Oxford: Blackwell Publishing, 2006, 272 pp., ISBN 9781405156363.] Relations industrielles / Industrial Relations, 65(1), 156-157.

https://doi.org/10.7202/039533ar

Tous droits réservés @ C Département des relations industrielles de l'Université Laval, 2009
Ce document est protégé par la loi sur le droit d'auteur. L'utilisation des services d'Érudit (y compris la reproduction) est assujettie à sa politique d'utilisation que vous pouvez consulter en ligne.

https://apropos.erudit.org/fr/usagers/politique-dutilisation/ 
al.). Ou encore, une comparaison régionale au Brésil soutient que les politiques publiques doivent se préoccuper de tous les enfants socialement vulnérables, tant les enfants des familles monoparentales que les enfants pauvres issus de configurations familiales plus conventionnelles (Sorj et Fontes). Une perspective théorique présentant l'origine et la définition de la conception de la division sexuelle du travail conclut cette seconde partie de l'ouvrage tout en dégageant les différences entre plusieurs pays sur le plan de l'évolution des modalités de conciliation entre la vie familiale et la vie professionnelle au Brésil, en France et au Japon, qu'il s'agisse de pratiques, de politiques familiales ou de norme sociale liée à l'emploi (Hirata et Kergoat).

Le troisième thème est axé sur le genre, les métiers et les carrières professionnelles. II débute par un article dressant l'évolution historique depuis le XIXe siècle des mutations économiques et sociales en Europe qui ont conduit les femmes à percer les professions diplômées (Schweitzer). Cette même auteure précise que nous vivons actuellement une nouvelle mutation sociale visant une répartition plus égalitaire des tâches entre les femmes et les hommes dans la sphère privée. En parallèle, cette mutation est lente compte tenu de la persistance du " plafond de verre » et de la résistance de la part des hommes à investir les sphères féminines traditionnelles (les soins par exemple). Les autres auteurs s'attardent sur les conditions de travail des femmes dans certaines professions, particulièrement au Brésil et en France. Ainsi, l'étude des rapports de genre dans les professions artistiques met en évidence la précarité croissante dans le domaine de la danse et de la musique de ces pays (Segnini). D'autres comparaisons entre la France et la Brésil portent, quant à elles, sur les changements en cours dans les relations et les conditions de travail des enseignants du secondaire (Neri de Souza) ou encore sur les relations entre la vie domestique et la vie professionnelle à partir d'une étude sur les ingénieurs du secteur des télécommunications (Georges). Finalement, en se penchant sur la pluralité des modèles de féminisation des professions supérieures, cette fois en France et en Grande-Bretagne, Le Feuvre fait valoir la diversification des expériences des femmes accédant aux « anciens bastions masculins ».
En définitive, cet ouvrage regorge de données sur la vie professionnelle et la vie familiale en Europe et en Amérique latine, menant à une plus grande compréhension de la question de l'inégalité entre les hommes et les femmes. Même si certaines différences existent entre les pays étudiés, les contributeurs de cet ouvrage convergent vers le constat d'une féminisation accrue du salariat, incluant les professions diplômées, combiné à la persistance d'iniquités entre les genres. Dès lors, les disparités salariales entre les hommes et les femmes, la ségrégation des emplois, la division sexuelle du travail, la question de la précarité et du chômage féminin, la difficile conciliation entre la sphère professionnelle et la sphère privée sont autant de phénomènes relevés quel que soit le pays à l'étude.

Même si ces constats ne sont pas nécessairement nouveaux et que certaines redondances sont parfois à déplorer, c'est le fait de faire appel à une perspective internationale mettant à l'avant-scène de nombreuses comparaisons entre les pays, à première vue sans lien apparent, qui rend l'ouvrage convaincant, enrichissant et accessible à toute lectrice ou lecteur se préoccupant de la logique du genre sur le marché du travail. Cette mise en commun, considérablement enrichie par l'apport de diverses disciplines, que ce soit la sociologie, l'histoire ou l'économie, conduit à de véritables pistes de réflexion et de solutions concrètes pour les politiques publiques, et ce, pour tous les pays étudiés.

\section{Catherine Le Capitaine}

Université Laval

\section{The Dirty Work of Neoliberalism: Cleaners in the Global Economy}

Edited by Luis L.M. Aguiar and Andrew Herod, Oxford: Blackwell Publishing, 2006, 272 pp., ISBN 9781405156363.

In this edited volume Luis Aguiar and Andrew Herod have brought together a collection of articles on the global cleaning industry principally organized into three thematic sections: geography, ethnography and agency. The book takes an expansive approach to considering labour relations in the cleaning industry. Not only do the editors bring together a collection of articles in which the experience of cleaners in the global north and the global 
south are put into relief, they provide commentary about the experiences of individual cleaners who are subject to increasing forms of intensive management. The authors distinguish between classic Taylorist managerial strategies (involving increasing levels of microsupervision with the goal of work intensification) and new innovations in cleaning machinery and surveillance technology. Their focus is on portraying the pressures that a globalized cleaning industry brings places on its workers. The last section of the book is dedicated to exploring different strategies of resistance to work intensification and provides examples of workers collective struggles in the furtherance of their common interests.

Overall, the work represents an ambitious attempt to reveal, what the authors' stress, is the hidden and largely invisible world of the cleaning industry, cleaning work and the particular challenges facing cleaning workers. One of the articles I found interesting was by Andries Bezuidenhout and Khayaat Fakier. These commentators do an excellent job at exposing the continuities and discontinuities between the pre and post apartheid labour relations regimes. Both the continuities and discontinuities will be disconcerting for those who believe that the circumstances of South African non-skilled workers have improved in the years since the end of apartheid.

The strength of this book is that it combines the work of different researchers and, in so doing, offers diverse perspectives of the same object of analysis. However, as is often the case in projects of this type and scope, this strength may also be seen as a weakness: the divergence of perspectives makes it difficult to achieve a single focus and overall thematic coherence. For example, as the title of the book makes clear, the editors seek to link the research contained inter alia to the broader political economy of what the authors see as a globalized neoliberalism. While I am sympathetic to this endeavour, I am uncertain if the book's contributions are sufficiently coordinated to adequately reveal that neoliberalism is an appropriate description of the structure of the global economy, or merely an ideology or policy paradigm. In this regard, the introductory remarks of the editors are too schematic.
My criticism of the book is minor. I would recommend the work to those with an interest in critical management studies, industrial relations, trade unionists and those who specialize in the sociology of work.

\section{Travis William Fast}

Université Laval

\section{Les nouveaux cadres du dialogue social : Europe et territoires}

Sous la direction de Annette Jobert, Bruxelles : Peter Lang, 2008, 267 p., ISBN 978-90-5201444-9.

L'ouvrage dirigé par Annette Jobert sur les nouveaux cadres du dialogue social est issu d'un travail collectif de recherche réalisé en 2004-2005 pour le Commissariat Général du Plan. II est constitué de quatre chapitres principaux qui explorent, dans une diversité de contextes, les enjeux du dialogue social au niveau européen et au niveau territorial. Les chapitres peuvent être lus à peu près indépendamment les uns des autres, I'introduction et la conclusion permettant d'approfondir les enjeux d'ensemble liés à la question du dialogue social. Les textes de l'ouvrage cherchent ainsi à caractériser l'évolution du dialogue social en Europe, et plus particulièrement en France, en croisant deux dimensions en pleine transformation : le niveau européen avec principalement les comités d'entreprise européens et le niveau territorial avec les régulations locales du travail et de l'emploi qui se sont développées notamment dans le contexte de la décentralisation des pouvoirs administratifs de l'État.

Trois hypothèses ont guidé les recherches sur les nouveaux cadres du dialogue social. La première hypothèse est que « la pertinence de l'espace de la négociation collective et du dialogue social dépend moins de l'objet de ce dialogue [...] que de la capacité des acteurs collectifs à se structurer dans cet espace et à y engager une action collective » (p. 15). Le premier chapitre du livre traite à travers trois situations, en Allemagne, en France et en Italie, des initiatives des acteurs syndicaux pour se saisir de l'occasion que représente la mise en œuvre de nouvelles régulations territoriales pour construire une action collective. Malgré la conclusion plutôt négative des auteurs sur cette capacité, les expériences décrites sont 